\title{
Evaluation of oxidative status in iron deficiency anemia through total antioxidant capacity measured using an automated method
}

\author{
Demir eksikliği anemisinde otomatik bir yöntem kullanılarak total \\ antioksidan kapasite ile oksidatif durumun değerlendirilmesi
}

\author{
Mehmet Aslan¹, Mehmet Horoz ${ }^{2}$, Hakim Çelik ${ }^{3}$ \\ ${ }^{1}$ Department of Internal Medicine Clinic, Özel Erciş Çapa Medicine Center, Van, Turkey \\ 2Department of Internal Medicine, Faculty of Medicine, Harran University, Sanliurfa, Turkey \\ ${ }^{3}$ Department of Clinical Biochemistry, Faculty of Medicine, Harran University, Sanliurfa, Turkey
}

\begin{abstract}
Objective: Oxidative stress, an increase in oxidants and/or a decrease in antioxidant capacity, is one of the potential biochemical mechanisms involved in the pathogenesis of iron deficiency anemia. The objective of this study was to evaluate the oxidative status and to determine whether there is any relationship between oxidative status and the severity of anemia in patients with iron deficiency anemia using an automated method.

Materials and Methods: Twenty-six subjects with iron deficiency anemia and 20 healthy controls were enrolled in the present study. Serum total antioxidant capacity, serum total peroxide level and oxidative stress index were determined in all study subjects.

Results: Serum total antioxidant capacity was significantly lower in patients with iron deficiency anemia than controls $(p<0.05)$, while serum total peroxide level and oxidative stress index were significantly higher (both $\mathrm{p}<0.05$ ). There was a significant correlation between hemoglobin level and serum total peroxide level, oxidative stress index and total antioxidant capacity $(r=-0.504, p<0.05 ; \mathrm{r}=-0.503$, $\mathrm{p}<0.05 ; \mathrm{r}=0.417, \mathrm{p}<0.05$, respectively).

Conclusion: Increased oxidative stress may play a role in the pathogenesis of iron deficiency anemia. Supplementation of antioxidant vitamins in conjunction with iron replacement therapy may offer better responses and provide early resolution of symptoms related to iron deficiency anemia. The automated assay is a reliable and easily applied method for measurement of serum total antioxidant capacity in iron deficiency anemia. (Turk J Hematol 2011; 28: 42-6)

Key words: Iron deficiency anemia, total peroxide, total antioxidant capacity, oxidative stress
\end{abstract}

Received: June 03, 2010

Accepted: August 19, 2010

\section{Özet}

Amaç: Oksidanlarda artış veya antioksidanlarda azalma olan oksidatif stres demir eksikliği anemisinin patogenezinde olası biyokimyasal mekanizmalardan biridir. Bu çalışmamızın amacı otomatik bir yöntem 


\begin{abstract}
kullanılarak demir eksikliği anemili hastalarda oksidatif durumu ve aneminin ciddiyeti ile oksidatif durum arasında herhangi bir ilişkinin olup olmadığını değerlendirmektir.

Yöntem ve Gereçler: Çalışmaya 26 demir eksikliği anemili hasta ve 20 sağlıklı kişi alındı. Tüm çalışma olgularında serum total antioksidan kapasite, total peroksit seviyesi ve oksidatif stres indeksi ölçüldü. Bulgular: Demir eksikliği anemili hastalarda serum total antioksidan kapasitesi kontrol grubuna göre anlaml derecede düşük bulunurken $(p<0.05)$, serum total peroksit seviyesi ve oksidatif stres indeksi ise anlamlı derecede yüksek bulundu (her ikisi için $p<0.05$ ). Hemoglobin seviyeleri ile serum total peroksit seviyesi, oksidatif stres indeksi ve total antioksidan kapasite arasında anlamlı bir korelasyon vardı (sıraslyla; $\mathrm{r}=-0.504, \mathrm{p}<0.05 ; \mathrm{r}=-0.503, \mathrm{p}<0.05 ; \mathrm{r}=0.417, \mathrm{p}<0.05)$.

Sonuç: Artmış oksidatif stres demir eksikliği anemisinin patogenezinde bir rol aynayabilir. Demir eksikliği anemili hastalarda demir replasman tedavisi ile birlikte antioksidan vitaminlerin verilmesi daha iyi yanıtlar sunabilir ve demir eksikliği anemisi ile ilgili semptomların erken düzelmesini sağlar. Bu otomatik test demir eksikliği anemisinde serum total antioksidan kapasitenin ölçümü için güvenilir ve kolay uygulanabilen bir yöntemdir. (Turk J Hematol 2011; 28: xx-xx)

Anahtar kelimeler: Demir eksikliği anemisi, total peroksit, total antioksidan kapasite, oksidatif stres
\end{abstract}

\section{Introduction}

Anemia is a pathologic condition in which there is a decrease in red blood cell mass or a decrease in the amount of hemoglobin. Iron deficiency is the most common nutritional problem worldwide, causing iron deficiency anemia (IDA) in approximately 500 to 600 million people [1]. Iron deficiency also affects the production of other $\mathrm{Fe}^{2+}$ containing proteins such as cytochromes, myoglobin, catalase (CAT) and peroxidase [2]. Thus, IDA is associated with prematurity and low birth weight during pregnancy, defects in cognitive and psychomotor development during childhood, and impaired work capacity in adulthood [3-5].

Reactive oxygen species (ROS) are oxygen-containing molecules that are produced during normal metabolism [6]. The organism has enzymatic and non-enzymatic antioxidant systems that neutralize the harmful effects of endogenous ROS products. Under certain conditions, the oxidative or antioxidative balance shifts towards the oxidative status as a result of an increase in ROS and/or impairment in the antioxidant mechanism. Thus, oxidative stress develops [7].

Increased oxidative stress in IDA subjects was reported in several studies, in which the oxidative status was evaluated using measurement of oxidants, individual antioxidants, or both [8-14]. In these studies, it has been reported that oxidants were increased and antioxidants were decreased, and as a result, the oxidative/anti-oxidative balance shifted toward the oxidative side in patients with IDA. Thus, increased oxidative stress may contribute to the pathogenesis of patients with IDA. To our best knowledge, oxidative status in IDA subjects and its relation to the severity of anemia were not previously investigated using a measurement of total antioxidant capacity (TAC) along with oxidants and calculation of the oxidative stress index (OSI), indicators of oxidative stress that reflect the redox balance between oxidation and antioxidation.

Thus, in the present study, we aimed to evaluate the oxidative status and to determine whether there is any relationship between oxidative status and the severity of anemia in IDA patients using measurements of TAC and total peroxide (TP) level and calculation of OSI.

\section{Materials and Methods}

A total of 26 female subjects with IDA and 20 healthy female controls were included in the present study. The study protocol was carried out in accordance with the Helsinki Declaration as revised in 1989 and approved by the local research committee for ethics. All subjects were informed about the study protocol and written consents were obtained from all participants.

Iron deficiency was defined as serum ferritin concentration $<15 \mu \mathrm{g} / \mathrm{L}$, indicating depleted iron stores; hemoglobin $(\mathrm{Hb})<10 \mathrm{~g} / \mathrm{dl}$ and a mean corpuscular volume (MCV) $<80 \mathrm{fl}$ and/or a mean corpuscular $\mathrm{Hb}$ concentration (MCHC) $<32 \mathrm{~g} / \mathrm{dl}$. In order to exclude the presence of thalassemia trait, subjects with MCV $<80 \mathrm{fl}$ underwent $\mathrm{Hb}$ electrophoresis, and examination of the blood smear for $\mathrm{Hb}-\mathrm{H}$ inclusion bodies was performed.

Routine blood biochemistry, tumor marker determination, stool examination for parasites, gynecologic examination, pelvic ultrasonography, and gas- 
trointestinal endoscopic examination were performed in all subjects with IDA.

Subjects with IDA were included if their biochemical, radiological and endoscopic examinations were normal. Most IDA subjects had regular menstrual bleeding; only three of them were considered to have dysfunctional menstrual bleeding. In all study subjects, IDA was considered to be secondary to the inadequate intake of an iron-containing diet despite the monthly iron loss through menstrual bleeding.

\section{Exclusion criteria}

Exclusion criteria included usage of supplemental vitamins and existence of diabetes mellitus, coronary artery disease, rheumatoid arthritis, malignancy, myoma uteri, systemic or local infection, hypertension, acute-chronic liver diseases, renal dysfunction, anemias other than IDA, and gastrointestinal parasitic diseases.

\section{Blood sample collection}

Blood samples were drawn after an overnight fast. Serum was separated by centrifugation at 1500 $g$ for 10 minutes (min) and stored at $-80^{\circ} \mathrm{C}$ until use.

\section{Measurement of serum total antioxidant potential}

Serum TAC was determined using a novel automated measurement method, developed by Erel [15]. In this method, hydroxyl radical - the most potent biological radical - is produced. In the assay, ferrous ion solution, which is present in Reagent 1 , is mixed by hydrogen peroxide, which is present in Reagent 2 . The sequentially produced radicals such as brown-colored dianisidinyl radical cation, produced by the hydroxyl radical, are also potent radicals. This method measures the antioxidative effect of the sample against the potent free radical reactions, which are initiated by the produced hydroxyl radical. The assay has excellent precision values lower than $3 \%$. The results are expressed as mmol Trolox Equivalent/L.

Measurement of total serum peroxide concentration

Serum TP concentrations were determined by an enzymatic assay as described previously [16]. The FOX2 test system is based on oxidation of ferrous ion to ferric ion by various types of peroxides contained within the serum samples, to produce a colored ferric-xylenol orange complex, the absorbance of which can be measured. Briefly, the FOX2 reagent was prepared by dissolving ammonium ferrous sulphate $(9.8 \mathrm{mg})$ in $250 \mathrm{mM} \mathrm{H}_{2} \mathrm{SO}_{4}(10 \mathrm{ml})$, to give a final concentration of $250 \mu \mathrm{M}$ ferrous ion in acid. This solution was then added to $90 \mathrm{ml}$ of HPLC-grade methanol containing $79.2 \mathrm{mg}$ butylated hydroxytoluene (BHT). Finally, $7.6 \mathrm{mg}$ xylenol orange was added while stirring to make the final working reagent $(250 \mu \mathrm{M}$ ammonium ferrous sulphate, $100 \mu \mathrm{M}$ xylenol orange, $25 \mathrm{mM} \mathrm{H}_{2} \mathrm{SO}_{4}$ and 4 $\mathrm{mM}$ BHT in $90 \% \mathrm{v} / \mathrm{v}$ methanol in a final volume of $100 \mathrm{ml}$ ). The blank reagent contained all the components of the solution except ferrous sulphate.

Aliquots $(200 \mu \mathrm{l})$ of serum were mixed with 1800 ml FOX2 reagent. After incubation at room temperature for $30 \mathrm{~min}$, the vials were centrifuged at 12000 $\mathrm{g}$ for $10 \mathrm{~min}$. Absorbance of the supernatant was then determined at $560 \mathrm{~nm}$. TP content of serum samples was determined as a function of the absorbance difference between sample and blank tubes using a solution of $\mathrm{H}_{2} \mathrm{O}_{2}$ as standard. The coefficient of variation for individual serum samples was less than $5 \%$.

\section{Oxidative stress index}

The percent ratio of the TP to the TAC gave the OSI, an indicator of the degree of oxidative stress [17].

\section{Other parameters}

Routine biochemical analyses were made using auto-analyzer (Aeroset ${ }^{\circledR}$, Abbott, Germany). Complete blood count was performed using Celdyne 3700 Haematology Analyser. Serum ferritin was measured using an immunometric assay (chemiluminescence) (Aeroset ${ }^{\circledR}$, Abbott).

\section{Statistical analysis}

All data were expressed as mean \pm standard deviation (SD). The comparisons of parameters were performed using Student's $t$ test, and correlation analyses were performed using Pearson's correlation test. A p value $<0.05$ was accepted as significant.

\section{Results}

Demographic and clinical data of the subjects are shown in Table 1. There were no significant differences between IDA subjects and controls with 
respect to age, gender and body mass index (BMI) (all $\mathrm{p}>0.05$ ).

TAC, TP level and OSI in IDA subjects and controls are shown in Table 2. TP and OSI were significantly higher in IDA subjects than controls (both $\mathrm{p}<0.05)$, while TAC was significantly lower $(\mathrm{p}<0.05)$.

A significant positive correlation was observed between TAC and Hb level $(r=0.417, p<0.05)$. On the contrary, TP level and OSI were negatively correlated with $\mathrm{Hb}$ level $(\mathrm{r}=-0.504, \mathrm{p}<0.05$ and $\mathrm{r}=-0.503$, $\mathrm{p}<0.05$, respectively).

\section{Discussion}

Normal cell functions and integrity of cell structures may be broken via considerable reactivity of ROS. The organism has enzymatic, such as superoxide dismutase (SOD), CAT, glutathione peroxidase (GSH-Px), and non-enzymatic (e.g. vitamin C, vitamin E) antioxidant mechanisms that work as scavengers against ROS [7].

In the present study, we observed that the patients with IDA are exposed to increased oxidative stress, and the potency of the oxidative stress is significantly related to the severity of anemia. The increase in oxidative stress that was observed in IDA subjects in the present study resulted from both increase in oxidants and decrease in TAC.

Table 1. Demographic and clinical parameters in controls and IDA patients

\begin{tabular}{lccc}
\hline Parameters & IDA $(\mathbf{n}=\mathbf{2 6})$ & Controls $(\mathbf{n}=\mathbf{2 0})$ & $\mathbf{p}$ \\
\hline Age (years) & $41 \pm 5$ & $40 \pm 6$ & $\mathrm{~ns}$ \\
BMI $\left(\mathrm{kg} / \mathrm{m}^{2}\right)$ & $22.4 \pm 1.8$ & $23.2 \pm 2.1$ & $\mathrm{~ns}$ \\
$\mathrm{Hb}(\mathrm{g} / \mathrm{dl})$ & $7.56 \pm 1.09$ & $15.40 \pm 1.60$ & $\mathrm{p}<0.001$ \\
Hct $(\%)$ & $25.7 \pm 2.78$ & $40.00 \pm 3.26$ & $\mathrm{p}<0.001$ \\
MCV (fl) & $63.71 \pm 7.40$ & $85.70 \pm 2.90$ & $\mathrm{p}<0.001$ \\
Ferritin ( $\mu \mathrm{g} / \mathrm{L})$ & $5.71 \pm 3.48$ & $76.35 \pm 33.28$ & $\mathrm{p}<0.001$
\end{tabular}

BMI: Body mass index; Hb: Hemoglobin; Hct: Hematocrit; MCV: Mean corpuscular volume; IDA: Iron deficiency anemia.Values are mean \pm SD; ns: non significant

Table 2. Oxidative and antioxidative parameters in controls and IDA patients

\begin{tabular}{lccc}
\hline Parameters & IDA $(\mathbf{n}=26)$ & Controls $(\mathbf{n}=20)$ & $\mathbf{p}$ \\
\hline TAC $(\mathrm{m}$ mol Trolox Eq./L) & $1.66 \pm 0.12$ & $1.76 \pm 0.10$ & $\mathrm{p}<0.05$ \\
TP ( $\mu$ mol H${ }_{2} \mathrm{O}_{2}$ Equiv./L) & $9.26 \pm 0.02$ & $6.86 \pm 0.12$ & $\mathrm{p}<0.05$ \\
OSI (Arbitrary Unit) & $5.57 \pm 0.16$ & $3.89 \pm 1.20$ & $\mathrm{p}<0.05$ \\
\hline
\end{tabular}

Values are mean \pm SD, TAC: Total antioxidant capacity; TP: Total peroxide; OSI: Oxidative stress index; IDA: Iron deficiency anemia
Oxidant levels and antioxidant enzyme activities such as SOD, GSH-Px and CAT have been evaluated in several studies [8-14]. Although conflicting results have been reported $[8,10]$, it is generally accepted that oxidative stress is increased through increase in oxidant levels and/or decrease in antioxidant enzyme capacities in IDA. Generally, decreased GSH-Px activity along with normal or increased SOD and CAT activity are the main findings in IDA [10,11]. However, in some studies, normal GSH-Px activity along with decreased SOD and CAT activity or decrease in all of these activities was also reported [12,13].

The effects of various antioxidants in serum are additive, and the cooperation of antioxidants in human serum protects the organism against attacks by free radicals [18]. Thus, measurement of individual antioxidants may not accurately reflect the true antioxidant status of the organism. In this regard, measurement of TAC should be essential in evaluating the true antioxidant status [12,15,19,20].

The most widely used methods for oxidative status measurement are colorimetric, or involve either fluorescence or chemiluminescence [21-23]. The fluorescence and chemiluminescence methods require sophisticated techniques, and these improved systems are not present in many routine clinical biochemistry laboratories. Even when these technologies are available, their routine usage is limited [20].

In the present study, we used an automated method, which has several major advantages in comparison with the other currently available methods, to measure TAC in our study population. It is simple and cheap, and can easily be a fully automated method. It is also reliable and sensitive, and does not interact with commonly occurring serum components such as bilirubin, serum lipids and anticoagulants. Accurate measurements of TAC can be obtained in as little as 10 minutes, making this assay imminently suitable for the clinical biochemistry laboratory [18].

Although our results were in concordance with the studies mentioned above with respect to increase in oxidative stress, none of the previous studies evaluated oxidative stress using TAC measurement. To our knowledge, this is the first study in which antioxidant capacity of IDA subjects was determined using measurement of TAC along with measurement of TP level and calculation of OSI. 
In light of these findings, we concluded that oxidative stress may have a critical role in the pathogenesis of IDA and is associated with the disease severity. Supplementation of antioxidant vitamins in conjunction with iron replacement therapy may offer better responses and provide early resolution of symptoms related to IDA. In addition, the automated assay is a reliable and easily applied method for serum TAC measurement in subjects with IDA.

\section{Conflict of interest statement}

None of the authors of this paper has a conflict of interest, including specific financial interests, relationships, and/or affiliations relevant to the subject matter or materials included.

\section{References}

1. DeMaeyer E, Adiels Tegman M. The prevalence of anaemia in the world. World Health Stat Q 1985;38:302-16.

2. Rockey DC, Cello JP. Evaluation of the gastrointestinal tract in patients with iron deficiency anemia. N Engl J Med 1993;329:1691-5. [CrossRef]

3. Lieberman E, Ryan KJ, Monson RR, Schoenbaum SC. Association of maternal hematocrit with premature labor. Am J Obstet Gynecol 1988;159:107-14.

4. Oski FA, Honig AS, Helu B, Howanitz P. Effect of iron therapy on behavior performance in nonanemic, irondeficient infants. Pediatrics 1983;71:877-80.

5. Basta SS, Soekirman MS, Karyadi D, Scrimshaw NS. Iron deficiency anemia and the productivity of adult males in Indonesia. Am J Clin Nutr 1979;32:916-25.

6. Chance B, Sies H, Boveris A. Hydroperoxide metabolism in mammalian organs. Physiol Rev 1979;59:527-605.

7. Halliwell B. Free radicals, antioxidants, and human disease: curiosity, cause, or consequence? Lancet 1994;344:721-4. [CrossRef]

8. Ramachandran M, Iyer GY. Erythrocyte membrane lipid peroxidation in iron deficiency anemia. Experientia 1984;40:173-4. [CrossRef]

9. Kumerova A, Lece A, Skesters A, Silova A, Petuhovs V. Anaemia and antioxidant defence of the red blood cells. Mater Med Pol 1998;30:12-5.

10. Jansson LT, Perkkio MV, Willis WT, Refino CJ, Dallman PR. Red cell superoxide dismutase is increased in iron deficiency anemia. Acta Haematol 1985;74:218-21. [CrossRef]

11. Macdougall LG. Red cell metabolism in iron deficiency anemia. The relationship between glutathione peroxi- dase, catalase, serum vitamin E, and susceptibility of iron-deficient red cells to oxidative hemolysis. J Pediatr 1972;80:775-82. [CrossRef]

12. Kurtoglu E, Ugur A, Baltaci AK, Undar L. Effect of iron supplementation on oxidative stress and antioxidant status in iron deficiency anemia. Biol Trace Elem Res 2003;96:117-23. [CrossRef]

13. Isler M, Delibas N, Guclu M, Gultekin F, Sutcu R, Bahceci M, Kosar A. Superoxide dismutase and glutathione peroxidase in erythrocytes of patients with iron deficiency anemia: effects of different treatment modalities. Croat Med J 2002;43:16-9.

14. Tekin D, Yavuzer S, Tekin M, Akar N, Cin S. Possible effects of antioxidant status on increased platelet aggregation in childhood iron-deficiency anemia. Pediatr Int 2001;43:74-7. [CrossRef]

15. Erel O. A novel automated method to measure total antioxidant response against potent free radical reactions. Clin Biochem 2004;37:112-9. [CrossRef]

16. Yeni E, Gulum M, Selek S, Erel O, Unal D, Verit A, Savas M. Comparison of oxidative/antioxidative status of penile corpus cavernosum blood and peripheral venous blood. Int J Impot Res 2005;17:19-22. [CrossRef]

17. Harma M, Harma M, Erel O. Increased oxidative stress in patients with hydatidiform mole. Swiss Med Wkly 2003;133:563-6.

18. Wayner DD, Burton GW, Ingold KU, Barclay LR, Locke SJ. The relative contributions of vitamin E, urate, ascorbate and proteins to the total peroxyl radical-trapping antioxidant activity of human blood plasma. Biochim Biophys Acta 1987;924:408-19.

19. Miller NJ, Rice-Evans C, Davies MJ, Gopinathan V, Milner A. A novel method for measuring antioxidant capacity and its application to monitoring the antioxidant status in premature neonates. Clin Sci (Lond) 1993;84:407-12.

20. Erel O. A novel automated direct measurement method for total antioxidant capacity using a new generation, more stable ABTS radical cation. Clin Biochem 2004;37:277-85. [CrossRef]

21. Schlesier K, Harwat M, Bohm V, Bitsch R. Assessment of antioxidant activity by using different in vitro methods. Free Radic Res 2002;36:177-87. [CrossRef]

22. Janaszewska A, Bartosz G. Assay of total antioxidant capacity: comparison of four methods as applied to human blood plasma. Scand J Clin Lab Invest 2002;62:231-6. [CrossRef]

23. Prior RL, Cao G. In vivo total antioxidant capacity: comparison of different analytical methods. Free Radic Biol Med 1999;27:1173-81. [CrossRef] 